\title{
PIPA CORPORATIVA: UMA FERRAMENTA DA TERAPIA NARRATIVA APLICADA ÀS FAMILIAS EMPRESÁRIAS
}

o ler a revista do mês de agosto, deparei-me com o artigo acima referido, que fez eco com a minha prática e vida pessoal. Tratar das questões de uma empresa familiar envolve tratar da própria família, uma vez que os problemas de um afetam o outro, vindo a comprometer o bom relacionamento interpessoal entre os membros da família e o desempenho da empresa. Penso que o nascimento de uma empresa familiar é similar a formar uma família: é preciso dedicar tempo, esforço físico e emocional para vê-la crescer e frutificar, o que gera expectativas e sonhos para o futuro. No entanto, assim como a família, pode ser também fonte de grandes desentendimentos, frustrações e mágoas que minam os vínculos, contaminando o ambiente profissional e comprometendo seu desempenho. Na família, são passados os valores, tradições, mitos; é onde os laços afetivos se desenvolvem. Lá existe um lugar e um papel para cada membro com suas respectivas hierarquias. Quando, na empresa, o lugar de cada um foi definido sem consenso, um emaranhado de papéis e sentimentos contamina os dois ambientes e dificulta tanto o relacionamento familiar como o desempenho da empresa.

As pesquisas apontam que os problemas geralmente aparecem em caso de morte ou doença do fundador que, na maior parte das vezes, não fez um planejamento sucessório ou de transição de poder entre os herdeiros, o que faz com que poucas empresas familiares cheguem à terceira geração.

Como terapeuta de família e mediadora de conflitos, tenho me interessado pelas práticas que visam ao resgate, nas pessoas, de seus recursos, seus valores, suas qualidades e que propiciem um olhar apreciativo do outro para fortalecer ou restabelecer vínculos desgastados. Orientada pelas premissas do Construcionismo Social e das práticas pós-modernas em que a ênfase é dada à linguagem e à interação entre as pessoas na compreensão dos processos de construção de sentido, considero que "tanto as palavras que usamos como o nome que atribuímos uns aos outros são usados para efetuar relações" (Gergen\&Gergen, 2010 p. 24), o que leva a adotar uma postura que, nas palavras de Anderson e Goolishian (1998), é de um parceiro conversacional. Desta forma, estar com as famílias em terapia ou mediação transformativa é trabalhar com um foco no diálogo e na construção conjunta de novos significados que possibilitem aos clientes se deslocarem do problema e agenciarem as soluções. Apoiada na premissa da linguagem como constitutiva, na criação conjunta de significados e na construção de novas narrativas de vida, a Terapia Narrativa desenvolvida por Michael White (2012) propõe que somos histórias contadas, as que nos contam e que contamos de nós; nesse processo, buscamos dar significado para nossas experiências de vida selecionando e interligando eventos que formam uma narrativa que se torna uma história de vida. Assim, entende-se que "todas as histórias são constitutivas de vida e dão forma às nossas vidas" (Morgan,

ANA LUISA ALMEIDA PRADO DE ANDRADE COUTINHO

Instituto Noos 
2007, p. 17). Essa prática que propõe separar o problema da pessoa, numa conversa de externalização, marcando que a pessoa é a pessoa e o problema é o problema, tem como objetivo promover uma conversa de "reautoria" ao dar luz a histórias que não foram selecionadas, eventos únicos, gerando novos significados para compor uma nova narrativa de vida. No meu trabalho profissional como terapeuta de família tive oportunidade de trabalhar com famílias a metodologia da Pipa da Vida e ver os resultados de uma maior integração da família, ao se conectarem com os sonhos, valores e pessoas importantes na vida de cada um. Sempre me encanta o efeito quase "mágico" que uma nova narrativa promove na vida das pessoas ao se descreverem com novos adjetivos, resgatarem valores, habilidades e competências, trazendo uma identidade preferida que estava periférica.

Outro desdobramento da terapia narrativa são as práticas narrativas coletivas, metodologia desenvolvida para trabalhar com comunidades em diferentes contextos, entre elas a família. David Denborough (2008) compilou algumas metodologias adequadas ao contexto coletivo, entre elas a Pipa da Vida, que desenvolveu no Canadá com famílias de imigrantes que viviam conflitos intergeracionais. A utilização desta metodologia empregada no contexto organizacional com empresas familiares despertou meu interesse e curiosidade por ver os resultados frutíferos e promissores que promoveu nas pessoas implicadas, como mudança nas relações e consequentemente no processo da empresa. $\mathrm{Pa}$ receu-me que de forma lúdica foi possível trabalhar temas difíceis e identificar as questões individuais trazidas do contexto familiar que estavam interferindo no contexto empresarial, impedindo ou atrapalhando a gestão da própria empresa, assim como a interação familiar. Ao externalizar o problema, foi possível reconhecer o que era de cada contexto; nas conversas de reautoria foi possível identificar os valores coletivos que circulam na família e na empresa. Criar um espaço conversacional para acolher e ressignificar eventos passados, ressentimentos ou pendências que mesclam a identidade pessoal com a função que cada um ocupa na empresa impedindo o seu manejo foi de extrema importância. Ainda mais, resgatar habilidades e competências conectando cada membro da família com a função com a qual tem mais afinidade e condições de desempenhar o trabalho permitiu dissolver conflitos que refletiam nos dois contextos. Tomar parte desse processo permitiu que todos pudessem finalizar com a criação de um documento coletivo definindo o que é da família e o que é da empresa, com vistas a preservar o funcionamento das duas. Na minha prática com famílias, já vivenciei o efeito do processo de dar voz para que cada um conte sua história e constatar um reconhecimento de si e do outro que promove sair de posições fixas e de discursos acusatórios para uma postura colaborativa. Dar visibilidade a um "evento único", neste caso a viagem que o pai fez com os filhos antes de morrer, possibilitou que resgatassem os valores da família e se conectassem uns aos outros com maior disposição para cuidar da manutenção dessas conquistas.

Segue para mim um convite a explorar criativamente a riqueza que essas práticas oferecem ao favorecer a criação de novas narrativas para trazer a melhor versão de cada um na criação/manutenção de projetos coletivos, seja na família, empresa familiar ou comunidade. Termino com esse poema de Fernando Pessoa que nos convida a desbravar novos caminhos. 
"Há um tempo em que é preciso abandonar as roupas usadas, que já têm a forma do nosso corpo, e esquecer os nossos caminhos, que nos levam sempre aos mesmos lugares. É o tempo da travessia: e, se não ousarmos fazê-la, teremos ficado, para sempre, à margem de nós mesmos”.

Fernando Pessoa

\section{REFERÊNCIAS}

Anderson, H. \& Goolishian, H. (1998). O cliente é o especialista: uma abordagem para terapia a partir de uma posição de não saber. In S. McNamee\& K.Gergen (Orgs.),Terapia como Construção Social (pp. 34-49). Porto Alegre: Artes Médicas.

Denborough, D. (2008).Práticas Narrativas Coletivas. Richmond, AUS: Graphic Print Group.

Gergen, K. J. \& Gergen, M. (2010).Construcionismo Social: um convite ao diálogo. Rio de Janeiro: Instituto Noos.

Morgan, A. (2007).O que é Terapia Narrativa? Porto Alegre: Centro de Estudos e Práticas Narrativas.

White, M. (2012).Mapas da Prática Narrativa. Porto Alegre: Pacartes.

\section{ANA LUISA ALMEIDA PRADO DE ANDRADE COUTINHO}

Terapeuta de Família e Casal, Mediadora de conflitos.

Integra a equipe do Instituto Noos, São Paulo.

Email: analuisacoutinho27@gmail.com 